DOI: $10.17148 / I A R J S E T .2021 .8912$

\title{
Growth regulator spray induced nutrient element variation in leaves of annual moringa (Moringa oleifera Lam.) Cv. PKM-1
}

\author{
Divyabharathi $V^{1}$, Swaminathan $V^{2}$, Paramaguru $P^{3}$, Venkatesan $K^{4}$ and Anitha $T^{5}$ \\ ${ }^{1}$ Senior Research Fellow, Department of Horticulture, Institute of Agriculture, Tamil Nadu Agricultural University, \\ Kumulur, Tiruchirappalli, Tamil Nadu. \\ ${ }^{2}$ Professor and Head Retd., Department of Horticulture, Agricultural College and Research Institute, Tamil Nadu \\ Agricultural University, Madurai, Tamil Nadu. \\ ${ }^{3}$ Dean (Horticulture), Horticultural College and Research Institute for Women, Tamil Nadu Agricultural University, \\ Tiruchirappalli, Tamil Nadu. \\ ${ }^{4}$ Professor (Crop physiology), Department of Floriculture and Medicinal Crops, Horticultural College and Research \\ Institute, Tamil Nadu Agricultural University, Periyakulam, Theni, Tamil Nadu. \\ ${ }^{5}$ Assistant Professor (Biochemistry), Department of Post-Harvest Technology, Horticultural college and Research \\ Institute, Tamil Nadu Agricultural University, Periyakulam, Theni, Tamil Nadu.
}

\begin{abstract}
Growth regulators, a group of synthetic chemicals have the capacity to create physical, physiological and nutritional changes in crops. The induced changes affect the hormonal balance, growth and development leading to improved yield and quality. The effect of diff erent growth regulators on mineral nutrients in leaf of annual moringa $C v$. PKM-1 was studied at field level under randomized block design with three replications. The mineral nutrients $(\mathrm{P}, \mathrm{K}, \mathrm{Ca}$, $\mathrm{Mg}, \mathrm{Cu}, \mathrm{Zn})$ in moringa leaves were assessed from control and treated plants $\left(\mathrm{GA}_{3} 20 \mathrm{ppm}, \mathrm{NAA} 20 \mathrm{ppm}, \mathrm{SA} 0.5 \%\right.$, Nitrobenzene $0.5 \%$, Paclobutrazol $20 \mathrm{ppm}$ and Mepiquat chloride $50 \mathrm{ppm})$. Paclobutrazol (20 ppm) was found effective in enhancing the mineral content of moringa leaves followed by Mepiquat chloride (50 ppm).
\end{abstract}

Keywords: Moringa, leaves, growth regulators, mineral elements

\section{INTRODUCTION}

Moringa (Moringa oleifera Lam.) is a single genus plant available in the family Moringaceae. It is multipurpose vegetable grown widely in tropical and sub-tropical regions of Indian and Africa. Moringa is a preferable vegetable in markets grown exclusively for edible pods and leaves. Every part of moringa like root, bark, gum, leaf, flowers, pods, seeds and seed oil are useful in one or other way in most of the indigenous medicines all over the world. Moringa has gained the commercial attention because of its nutritive properties, richness in amino acids, flavonoids, phenolics, minerals and folate. Moringa serves as medicine, nutraceuticals, water purifier as well as source for biodiesel production and hence it is referred as a miracle tree.

Moringa leaves are in great demand world-wide. Leaves as fresh and in dry form considered as significant food source, used as a nutrient supplement for vitamins A, B, and C, riboflavin, nicotinic acid, folic acid, pyridoxine, starch, calcium, iron and alpha-tocopherol (Fuglie, 2001). Micronutrient deficiencies are the major factor contributing to various diseases (Dhakar et al. 2014). Malnutrition can be alleviated by making use of naturally available food substances. Considering the nutrient status of leaves and need to alleviate the malnutrition, the mineral status of this crop has been focused to enhance mineral content availability.

\section{EXPERIMENTAL METHODS}

The trial was conducted at the Department of Vegetable Science, Horticultural College and Research, Periyakulam, during 2019-20. The experiment was laid out in randomized block design with three replications. Seeds of annual moringa cv. PKM-1 were sown in an area of 0.63 acres with a spacing of $3 \mathrm{mx} 3 \mathrm{~m}$. The trees were sprayed with six different growth regulators along with a control. The six growth regulators include Nitrobenzene $0.5 \%, \mathrm{GA}_{3} 20$ ppm, NAA 20 


\section{DOI: 10.17148/IARJSET.2021.8912}

ppm, SA $0.5 \%$, Mepiquat chloride 50 ppm and Paclobutrazol 20 ppm. The leaf samples were collected two weeks after the second spray.

The collected leaves were dried and used for the quality parameter (P, K, Ca, Mg, Cu and Zn) analysis. The phosphorous content was estimated using vanadomolybdate yellow colour method propsed by Jackson et al. (1973) and expressed in per cent (\%). The potassium content was estimated using Piper's (1944) flame photometric method and expressed in mg per $100 \mathrm{~g}$. The calcium content was estimated using the EDTA method proposed by Jackson et al. (1973) and expressed in per cent (\%). The magnesium content was estimated using versanate method (Jackson et al., 1973) and expressed in per cent (\%). The Copper and Zinc content was estimated using atomic absorption spectrophotometer as proposed by Jackson et al. (1973) and expressed in $\mu \mathrm{g}$ per $\mathrm{g}$ and $\mathrm{mg}$ per $100 \mathrm{~g}$ respectively. The data obtained were statistically analysed as per the methods of Panse and Sukhatme (1967) using agres statistical software.

\section{RESULTS AND DISCUSSION}

The spray of different growth regulators shows significant impact on potassium, calcium, magnesium and zinc content of moringa leaves (Table 1.). No significant effect was observed in the amount of phosphorus and copper content of moringa leaves. Spraying of paclobutrazol $20 \mathrm{ppm}$ increased the potassium (77.99 mg/100g), calcium (2.88 \%) and magnesium $(1.15 \%)$ content of leaves. Zinc content was enhanced by the application of $\mathrm{GA}_{3} 20$ ppm. The mineral contents were equally increased in mepiquat chloride $50 \mathrm{ppm}$ spray as that of in paclobutrazol spray. Paclobutrazol is often referred as multi stress protectant due to its potential to mitigate the effects of various abiotic stress on growth and development of the crops by regulating the level of hormones, enzymatic and non-enzymatic antioxidants and osmolytes (Kamran et al., 2018).

Application of paclobutrazol improved the root activity through enlarging the root diameter along with cortex width, favoured the induction of more secondary xylem vessels. Increased root area influences the potassium and calcium uptake (Baysan and Lynch, 2007). Low hydraulic conductivity and daily water uptake influenced by paclobutrazol might have influenced the improved calcium and magnesium uptake (Bowling, 1976). Accumulation of minerals by mepiquat chloride spray in moringa leaves was on par with paclobutrazol spray.

Mepiquat chloride being a retardant reduces the vegetative growth and thus increased possibility of storage of elements in the available vegetation at an increased rate (Sharples and Johnson, 1985). Zinc plays a significant role in auxin biosynthesis. Synthetic auxin spray competes with the native auxin for the site of action. Competition between two molecules stimulates the plant oxidases activity. Those oxidases destroy both auxin and the native auxin (IAA) will be synthesized after a short period of time (Gowing, 1956). This might have influenced the increased uptake of $\mathrm{Zn}$ for the synthesis of IAA to balance the loss.

Table 1. Effect of growth regulators on mineral content in leaves of annual moringa 'PKM 1'

\begin{tabular}{|l|l|l|l|l|l|l|}
\hline Treatments & $\begin{array}{l}\text { Phosphorous } \\
\text { content }(\%)\end{array}$ & $\begin{array}{l}\text { Potassium } \\
\text { content } \\
(\mathbf{m g} / \mathbf{1 0 0 g})\end{array}$ & $\begin{array}{l}\text { Calcium } \\
\text { content }(\%)\end{array}$ & $\begin{array}{l}\text { Magnesium } \\
\text { content }(\%)\end{array}$ & $\begin{array}{l}\text { Zinc content } \\
(\mathbf{m g} / \mathbf{1 0 0 g}) \\
\text { content } \\
(\boldsymbol{\mu g} / \mathbf{g})\end{array}$ \\
\hline $\mathbf{T}_{\mathbf{1}}$ & 0.026 & 73.71 & 2.13 & 0.67 & 1.40 & 16.63 \\
\hline $\mathbf{T}_{\mathbf{2}}$ & 0.030 & 69.76 & 2.80 & 0.82 & 1.83 & 16.16 \\
\hline $\mathbf{T}_{\mathbf{3}}$ & 0.018 & 64.17 & 2.11 & 1.23 & 1.49 & 16.35 \\
\hline $\mathbf{T}_{\mathbf{4}}$ & 0.016 & 71.41 & 1.97 & 0.77 & 0.92 & 16.39 \\
\hline $\mathbf{T}_{\mathbf{5}}$ & 0.018 & 75.68 & 1.81 & 1.15 & 1.58 & 16.33 \\
\hline $\mathbf{T}_{\mathbf{6}}$ & 0.031 & 77.99 & 2.88 & 1.27 & 0.92 & 16.32 \\
\hline $\mathbf{T}_{\mathbf{7}}$ & 0.017 & 77.00 & 1.65 & 0.64 & 0.63 & 16.02 \\
\hline Mean & $\mathbf{0 . 0 2 2}$ & $\mathbf{7 2 . 8 2}$ & $\mathbf{2 . 1 9}$ & $\mathbf{0 . 9 4}$ & $\mathbf{1 . 3 7}$ & $\mathbf{1 6 . 3 1}$ \\
\hline SEd & $\mathbf{0 . 0 0 6}$ & $\mathbf{1 . 7 6 9}$ & $\mathbf{0 . 3 2 6}$ & $\mathbf{0 . 2 1 9}$ & $\mathbf{0 . 1 7 4}$ & $\mathbf{0 . 3 6 0}$ \\
\hline $\mathbf{C D}(\mathbf{0 . 0 5})$ & $\mathbf{0 . 0 1 3}$ & $\mathbf{3 . 8 5 4} * *$ & $\mathbf{0 . 7 1 1} *$ & $\mathbf{0 . 4 7 7} *$ & $\mathbf{0 . 3 7 9} * *$ & $\mathbf{0 . 6 4 8}$ \\
\hline
\end{tabular}

\section{CONCLUSION}

Growth regulators are a great boon to the crops and farmers as it supports the crop growth as well as enhance the income of the farmers. Moringa is a miracle tree, a cheap source of nutraceutical. To enhance the available mineral element content in moringa leaves growth regulators are of great use. In conclusion, spraying Paclobutrazol (20 ppm) and Mepiquat chloride $(50 \mathrm{ppm})$ is beneficial to harness the maximum potential of moringa leaves. 


\section{International Advanced Research Journal in Science, Engineering and Technology}

Vol. 8, Issue 9, September 2021

DOI: 10.17148/IARJSET.2021.8912

\section{REFERENCES}

1. Baysan, A, and E Lynch. 2007. Clinical reversal of root caries using ozone: 6-month results. American journal of dentistry. 20 (4): $203-208$.

2. Bowling, DJF. 1976. Uptake of ions by plant roots: Chapman and Hall.

3. Dhakar RC, SD Maurya, BK Pooniya, N Bairwa, M Gupta and Sanwarlal. 2014. Moringa: The herbal gold to combat malnutrition. Chronicles of young scientists. 2(3): 119-125.

4. Fuglie LJ. 2001. The miracle tree: The multiple attributes of Moringa. P: 172.

5. Gowing, DP 1956. "An Hypothesis of the Role Naphthaleneacetic Acid in Flower Induction in the Pineapple." American Journal of Botany. Pp: 411-418.

6. Jackson, ML, RH Miller and RE Forkiln. 1973. Soil chemical analysis. Prentic-Hall of India Pvt. \& Ltd., New Delhi: 2nd Indian Rep.

7. Kamran, M, S Wennan, I Ahmad, M Xiangping, C Wenwen, Z Xudong, M Siwei, A Khan, H Qingfang and L Tiening. 2018. Application of paclobutrazol affect maize grain yield by regulating root morphological and physiological characteristics under a semi-arid region. Scientific Reports. 8 (1): $1-15$

8. Panse, VG, and PV Sukhatme. 1954. Statistical methods for agricultural workers.

9. Piper, CS. 1944. Soil and plant analysis: a laboratory manual of methods for the examination of soils and the determination of the inorganic constituents of plants: Interscience publishers, inc.

10. Sharples, RO, and DS Johnson. 1985. Effects of some growth regulators on the ripening and storage quality of apples and pears. V International Symposium on Growth Regulators in Fruit Production 179.

11.HIMANSHU SEKHAR BEHERA; Bijoy kumar pany. "Soil properties of medium land rice (Oryza sativa L.) in inorganic nitrogenous fertilizers on fym combination in yield". International Research Journal on Advanced Science Hub, 3, Special Issue ICIES-2021 4S, 2021 , 46-49. doi: 10.47392/irjash.2021.109 